\title{
Reação em cadeia da polimerase da transcrição reversa em tempo real
}

\author{
Real-time reverse transcription polymerase chain reaction
}

Pedro Ribeiro Soares de Ladeira', Cesar Isaac ${ }^{2}$, Marcus Castro Ferreira ${ }^{3}$

Ladeira PRS, Isaac C, Ferreira MC. Reação em cadeia da polimerase da transcrição reversa em tempo real/ Real-time reverse transcription polymerase chain reaction. Rev Med (São Paulo). 2011 jan.-mar.;90(1):47-51.

RESUMO: RT-qPCR é um dos métodos de mensurar expressão gênica mais difundidos e confiáveis utilizados atualmente. Primeiro, realiza-se extração do RNAm de um grupo celular homogêneo para poder realizar a fase RT (transcrição reversa). Neste momento a enzima transcriptase reversa sintetiza o DNAc correspondente de cada fita de RNA. Em seguida inicia-se a qPCR (reação em cadeia da polimerase em tempo real), que recebe esse nome por dar resultados quantitativos ("q" de qPCR), diferentemente dos qualitativos da PCR convencional. Essa etapa caracteriza-se pela amplificação de um sítio específico no conjunto de DNAc, que ocorre, resumidamente, por meio do uso de uma DNA polimerase DNA-dependente termoestável (Taq polimerase), dois oligômeros específicos para servirem de iniciadores para a polimerase (primers) e um fluoróforo não específico de DNA (SYBR Green I, por exemplo). Conforme as cadeias duplas do DNAc-alvo vão sendo sintetizadas, o fluoróforo se liga a elas e, após ser excitado, emite luz proporcionalmente ao número de cadeias duplas. Através de análise gráfica pode-se quantificar a amostra inicial de DNAc que, na ausência de erros, é proporcional a de RNAm.

DESCRITORES: Reação em cadeia da polimerase; Transcrição reversa/genética; DNA; RNA.
ABSTRACT: RT-qPCR is one of the most widespread and reliable methods of measuring gene expression. First, the extraction of mRNA from a homogeneous cell group is done in order to perform the RT phase (reverse transcription). At this point the reverse transcriptase enzyme synthesizes cDNA corresponding to each RNA strand. Then begins the qPCR (real time polymerase chain reaction), which gets its name because it gives quantitative results ("q" of qPCR), unlike the conventional PCR qualitative results. This stage is characterized by amplification of a specific site in the set of CDNA, which is achieved, briefly, through the use of a DNA-dependent thermostable DNA polymerase (Taq polymerase), two oligomers specific to serve as primers for polymerase and a non-specific DNA fluorophore (SYBR Green I, for example). As the double-strand cDNA is being synthesized, the fluorophore binds to its strands and, after being excited, emits light in proportion to the number of double chains. Through graphical analysis, it is possible to quantify the initial sample of cDNA that, in absence of errors, is proportional to mRNA.

KEYWORDS: Polymerase chain reaction; Reverse transcription/ genetics; DNA; RNA.

\footnotetext{
1. Acadêmico do Curso de Medicina da Faculdade de Medicina da Universidade de São Paulo (FMUSP).

2. Médico responsável pelo Laboratório de Pesquisa em Cultura Celular e Feridas - LIM 04 HCFMUSP.

3. Professor Titular da Disciplina de Cirurgia Plástica da Faculdade de Medicina da Universidade de São Paulo (FMUSP) e Diretor Técnico da Divisão de Cirurgia Plástica e Queimados - HCFMUSP.
}

Endereço para correspondência: Cesar Isaac. LIM 04 - Av. Dr. Arnaldo 455 - sala 1363 - Cerqueira Cesar - São Paulo, SP. CEP: e-mail: cesaris@ plastica.fm.usp.br. 


\section{RT-qPCR}

A reação de amplificação em tempo real, uma variante da reação de PCR convencional, representa grande avanço nos métodos moleculares de auxílio diagnóstico, particularmente por facilitar sobremaneira as tarefas de quantificação da expressão gênica em determinado tecido ou amostra biológica. Um exemplo muito bem conhecido é o da leucemia mielóide crônica (LMC), que apresenta de maneira constitutivamente elevada a expressão do transcrito BCR-ABL. Esse gene quimérico, produto da fusão dos genes BCR e $A B L$, pode não apenas ser detectado, firmando o diagnóstico da doença mieloproliferativa, mas ter seu nível de expressão aferido ao longo de determinada intervenção terapêutica. Dessa forma, constitui excelente marcador para avaliar precocemente a resposta da LMC ao tratamento.

Buscando entender os mecanismos moleculares envolvidos na fisiologia, patologia, desenvolvimento e respostas terapêuticas, foram desenvolvidas técnicas que fornecessem informações gênicas sobre as células ${ }^{1}$. Desde então e ainda mais após o sequenciamento completo do genoma humano em $2004^{2}$, o tema central das pesquisas de função de genes tornou-se a expressão do $D_{N A}{ }^{3}$ Uma das abordagens dessa área é a quantificação dos níveis de transcrição, a qual é mais popularmente realizada por meio da qRT-PCR (reação em cadeia da polimerase da transcrição reversa em tempo real - real-time reverse transcription polymerase chain reaction), técnica que envolve: transcrição reversa (RT da sigla), reação em cadeia da polimerase (PCR) e análise desta última assim que seus produtos se formam, ou seja, em tempo real (o "q" de qRT$\mathrm{PCR})^{4}$.

Transcrição reversa é a reação de formação de DNA fita dupla (cDNA ou DNA complementar) a partir de RNA (RNAm ou RNA mensageiro) por uma DNA polimerase RNA-dependente, ou seja, uma enzima que produz DNA a partir de um molde de RNA (Figura 1).

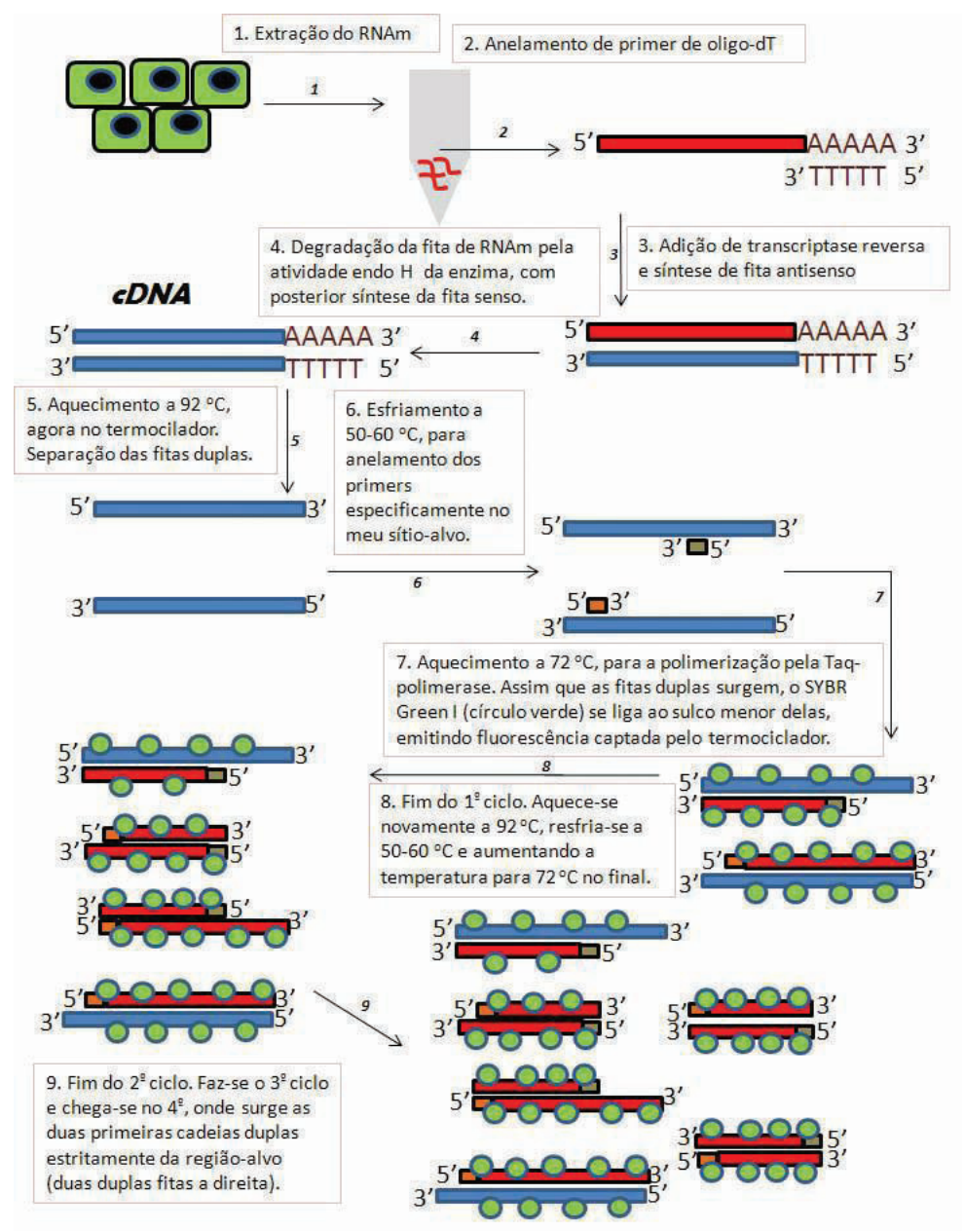

FIGURA 1. Representação esquemática de uma reação de RT-qPCR com uso de SYBR Green I 
Visando resultados comparáveis é importante obter a amostra mais pura possível quanto ao tipo celular, e para tanto se podem usar microdissecção por captura a laser (LCM, laser-capture microdissection), culturas celulares e separador eletrônico de células ativado por fluorescência (FACS, fluorescent activated cell sorter). O produto desses métodos deve então ser submetido à lise celular para posterior isolamento do $\mathrm{RNAm}^{5,6}$. Uma das formas de realizar esta tarefa em uma única etapa é com guanidina isotiocianato, fenol e clorofórmio, conjunto comercialmente chamado de reagente $\mathrm{TRIzo}^{\circledR}$. Ele atua durante a ultracentrifugação da amostra celular, lisando células e separando o conteúdo em fase aquosa superficial e orgânica profunda, compostas, respectivamente, pelo RNA total e pelos outros componentes celulares, ficando o DNA na interface das fases ${ }^{7}$.

O RNA a ser utilizado no processo é RNAm pós-processamento, ou seja, que já passou por splicing (retirada dos íntrons), capeamento da extremidade ${ }^{\prime}$ e poliadenilação da $3^{\prime 8}$. Para dar início à transcrição reversa deve-se escolher uma transcriptase reversa com atividade endo-H ou RNAse $\mathrm{H}$ (degradação do RNA após a síntese da fita anti-senso, para permitir a formação da fita senso pela transcriptase reversa), como as sintéticas (ex: Superscript II), que têm atividade polimerase aumentada e, nuclease, diminuída. Neste ponto do processo é importante atentar à possível estrutura secundária do RNAm e, portanto, realizar a reação a temperatura alta o suficiente para desnaturar esse ácido nucleico e ainda obter boa atividade enzimática ${ }^{1,3,9}$. Além disso, também é imperativo primer para início do processo, podendo-se escolher um oligômero de timinas (oligodT), o qual se ligará a cauda poli- $\mathrm{A}^{10}$.

Deste modo, juntamente da transcriptase reversa e primer, devem-se colocar quatro tipos de deoxinucleosídeos trifosfatos (dNTPs: dATP, dTTP, dGTP e dCTP) e cátion bivalente de magnésio $\left(\mathrm{Mg}^{2+}\right)$, metal imprescindível à reação e que atua aumentando os pontos de interação entre NTPs/dNTPs e as enzimas que os têm como substrato ${ }^{3,11}$.

No final da fase RT, em condições ideais, haverá quantidades proporcionais de DNAc e RNAm, e pelo menos um do primeiro para cada um do segundo ${ }^{1,5}$.

Como a integridade e quantidade de RNA total normalmente não são garantidas, é importante fazer, por exemplo, eletroforese em gel com brometo de etídio como fluoróforo, como fez em seu trabalho Wehkamp et al. ${ }^{12}$. Para validar a transcrição reversa, podem-se usar controles para cálculo da variabilidade entre as reações, mostrando a reprodutibilidade do experimento ${ }^{6}$.

Neste momento tem início a PCR, que será analisada em tempo real. Outra forma de se referir a esta etapa é pela sigla qPCR, que está relacionada à diferença entre este tipo de procedimento e a PCR convencional: quantificação do RNAm-alvo. A junção de PCR convencional, fluoróforo e videografia em tempo real resultou na criação da qPCR 1 .

A PCR (reação em cadeia da polimerase, polymerase chain reaction) permite que uma sequência do genoma seja amplificada um bilhão de vezes, purificando-a do restante do $D N A^{5}$. No caso, é o DNAc-alvo que passará pelo processo, sendo o par de primers, um para cada fita simples que o compõe, escolhido conforme sua sequência de bases. Entretanto, não há necessidade de clonar todo o DNAc, devendo haver entre 100 a 600 bases entre os primers, que, por sua vez, devem ter cerca de 20 nucleotídeos $^{10}$. Deve-se escolher um sítio de ligação confiável para os primers, atentando para possíveis polimorfismos ou mutações ${ }^{4}$.

Para permitir anelamento dos primers será necessário elevar a temperatura até separar cada fita dupla de DNA em duas simples. Porém, a DNA polimerase DNA-dependente não pode ter sua eficiência enzimática afetada. Visando solucionar esse empecilho começou-se o uso de DNA polimerase derivada de uma arqueobactéria (Thermus aquaticus) resistente a altas temperaturas juntamente com sua DNA polimerase: Taq polimerase ${ }^{1,13}$.

Adicionando tampão (para estabilizar o $\mathrm{pH}), \mathrm{Mg}^{2+}$ e dNTPs à mistura contendo primers, Taq polimerase e amostra de DNA, pode-se dar início à sequência de ciclos de PCR. Inicialmente eleva-se a temperatura a aproximadamente $92^{\circ} \mathrm{C}$, dissociando-se as duplas fitas de DNA; abaixa-se a temperatura para entre 50 e $60^{\circ} \mathrm{C}$, permitindo anelamento dos primers às suas sequências específicas correspondentes; eleva-se a cerca de $72^{\circ} \mathrm{C}$, onde a atividade da Taq polimerase é ótima, terminando o primeiro ciclo. Voltase aos $92^{\circ} \mathrm{C}$ para o início de outro ciclo; repetindo-se o procedimento, normalmente, até se atingir a marca de 40 ciclos, onde haverá cerca de 1 bilhão de cópias da sequência dupla fita alvo (Figura 1$)^{10}$.

$\mathrm{Na}$ qRT-PCR, acrescenta-se um fluoróforo no procedimento da qPCR, sendo preferencialmente o SYBR Green I, por se ligar principalmente a fitas duplas e aumentar até 1000 vezes sua fluorescência quando está ligado ao DNA. Assim como brometo de etídio, SYBR Green I atua na dupla fita, ligando-se ao sulco menor do DNA e emitindo luz de $520 \mathrm{~nm}$ de comprimento de onda quando excitado com luz de $480 \mathrm{~nm}$ (Figura 1). A qualidade de emitir luz quando excitado é típica de fluoróforo, e evidencia que uma máquina de QPCR deve ser capaz de emitir e detectar luz'.

O sinal de fluorescência irá crescer 
conforme os ciclos progridem, sendo captado pelos fotodetectores do aparelho de qPCR e convertido em gráficos por um software que captura e analisa os dados $^{1}$. Entretanto, como este sinal pode ser alterado por flutuações externas à qPCR ou diferenças entre volumes dos masters mixers (nome dos kits comerciais de PCR), deve-se usar junto um fluoróforo passivo, como ROX, e dividir os números do SYBR Green I pelos correspondentes do ROX. O resultado desta divisão é chamado de Rn (relato normalizado, normalized repórter) (Figura 2$)^{6}$.

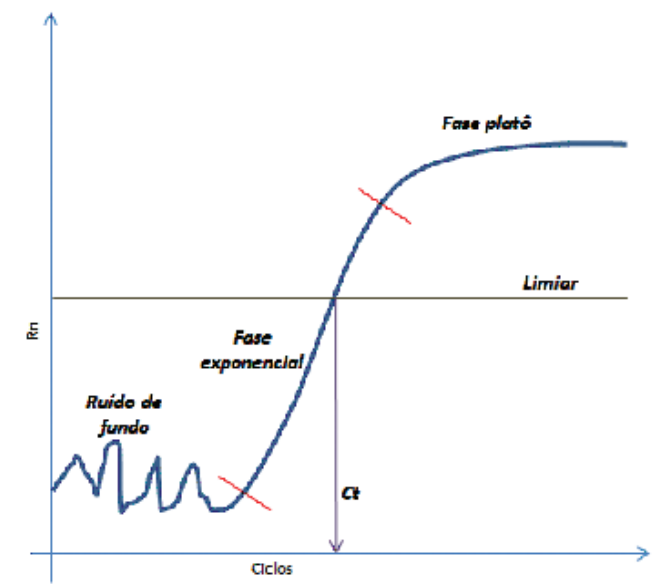

FIGURA 2. Exemplo de gráfico Rn por ciclos de qPCR. Pode-se verificar as três fases do gráfico: ruído de fundo, exponencial e platô, juntamente com a fluorescência limiar e o Ct

A diferença entre qPCR e PCR convencional é a quantificação da amostra inicial de DNA, sendo o porquê da letra "q" da sigla (quantification) ${ }^{1}$. Esta, por sua vez, pode ser feita de maneira absoluta ou relativa. A primeira, diferentemente da segunda, não envolve uma matemática complexa, mas é mais trabalhosa manualmente. Visando um raciocínio mais simples, será escolhida quantificação absoluta. Ela se baseia no gráfico $\Delta$ Rn por ciclo de qPCR corrente, sendo $\Delta \mathrm{Rn}$ o $\mathrm{Rn}$ captado subtraído do ruído de fundo (background noise) da fase patamar (baseline), que se trata da quantidade de fluorescência verificada em um controle negativo (todos os componentes da qPCR, mas sem amostra de DNA) ${ }^{6}$. Após essa fase inicial de patamar, começa a ocorrer aumento exponencial no $\Delta R n$, representando o momento de amplificação máxima da amostra. Entretanto, com o tempo e esgotamento dos reagentes, a curva alcança um platô, caracterizado por valor aproximadamente constante no $\Delta R n$, mesmo que os ciclos continuem a serem feitos. É na fase exponencial que se determina o limiar (threshold): linha com $\Delta R n$ constante, sendo cruzada pela curva em um ponto onde o ciclo correspondente receberá o nome de $\mathrm{Ct}$ (ciclo limiar, threshold cycle). Este Ct representa o momento em que a fluorescência emitida corresponderá à quantidade de DNA inicial ${ }^{1,6}$ (Figura 2).

Para poder fazer a quantificação de fato, necessita-se de uma amostra do DNAc de interesse cuja concentração seja conhecida. São feitas diluições da amostra em diferentes concentrações, em que se saiba seu número final, e faz-se a qPCR delas para conhecer o $\mathrm{Ct}$ de cada. Obtendo-se um gráfico $\mathrm{Ct}$ por log da concentração após a diluição, podem-se procurar os números de $\mathrm{Ct}$ das amostras em que não há conhecimento da concentração inicial ${ }^{6,12}$.

O software que analisará os dados da qPCR também fornecerá gráfico da temperatura de dissociação (Tm, melting temperature) dos produtos. $\mathrm{Na}$ abscissa estarão os graus Celsius e, na ordenada, valor numérico correspondente ao oposto da quantidade de fluorescência por unidade de tempo (Figura 2). Isto porque, na temperatura de dissociação, há queda rápida na fluorescência, que aparecerá como pico na curva do gráfico. Como Tm é específico de cada cadeia dupla de DNA (tamanho e composição de bases nitrogenadas), este método é um bom controle quanto ao número de amostras obtidas (Figura 3$)^{10}$.

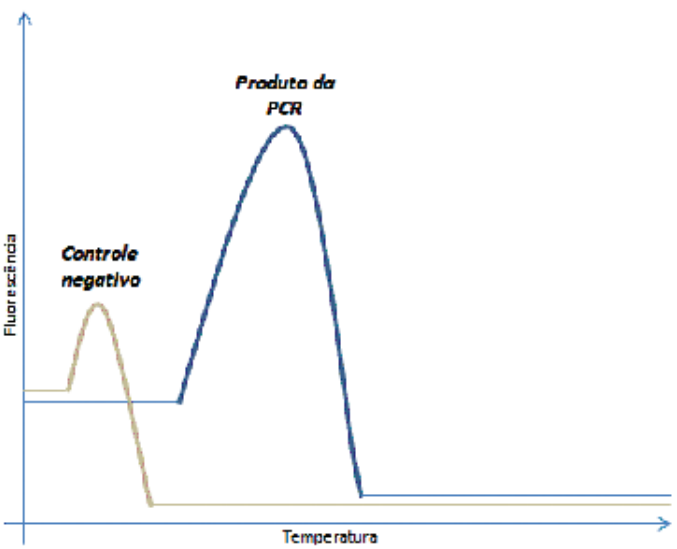

FIGURA 3. Exemplo de gráfico de Tm, temperatura em que cada dupla fita final da qPCR se dissocia. Há um pico menor inicial correspondente a separação dos dímeros de primers do controle negativo, artefato comum em experimentos com excesso de iniciadores

Para melhor validar o procedimento é interessante realizar na qPCR: controle negativo, com todos os reagentes, mas sem a amostra de DNA, e, positivo, com DNAc de gene endógeno (housekeeping gene). Este último é idealmente expresso de modo equivalente por todas as células utilizadas e pode ser usado como parâmetro de comparação para outros DNAc. Dois exemplos comuns são o da $\beta$-actina e do gliceraldeído-3-fosfato desidrogenase (GAPDH). Como um gene endógeno pode não ser expresso por todas as células, é interessante validá-lo na amostra antes de usá-lo no experimento ${ }^{6,10}$. 
Apesar de sua popularidade, a RT-qPCR é muito passível de variações, dificultando sua reprodutibilidade. Isso ocorre porque há grande variedade de empresas fabricando termocicladores e reagentes, havendo particularidades para cada um deles e variações até mesmo dentro da mesma empresa. Entretanto, a maior causa de variação continua sendo o operador e, mais especificamente, durante a fase de RT, quando ele se faz mais

\section{REFERÊNCIAS}

1. Valasek MA, Repa JJ. The power of real-time PCR. Adv Physiol Educ. 2005;29:151-9.

2. Berg JM, Tymoczko JL, Stryer L. Bioquímica. Rio de Janeiro: Guanabara Koogan; 2008. p.137-61.

3. Bustin SA. Absolute quantification of mRNA using realtime reverse transcription polymerase chain reaction assays. J Mol Endocrinol. 2000;25:169-93.

4. Bustin SA, Mueller R. Real-time reverse transcription PCR ( $q R T-P C R$ ) and its potential use in clinical diagnosis. Clin Sci. 2005;109:365-79.

5. Alberts B, et al. Biologia molecular da célula. Porto Alegre: Artmed; 2004. p.470-512.

6. Wong ML, Medrano JF. Real-time PCR for mRNA quantitation. BioTechniques. 2005;39;75-85.

7. Simms D, Cizdziel PE, Chomczynsk P. TRIzol ${ }^{\mathrm{TM}}$ : a new reagent for optimal single-step isolation of RNA. Focus. 1998;15:99-103.

8. Alberts B, et al. Biologia molecular da célula. Porto necessário. Isso pode ser explicado tanto pela diferença de habilidades de cada indivíduo, como a de protocolos seguidos ${ }^{1,6}$.

Mesmo com variabilidade experimental, por meio de um experimento bem planejado aplicado com controles adequados, a RT-qPCR é um dos mais sensíveis, eficientes, específicos e rápidos métodos de medida de expressão gênica a serem escolhidos ${ }^{1,6}$.

Alegre: Artmed; 2004. p.300-64.

9. Alberts B, et al. Biologia molecular da célula. Porto Alegre: Artmed; 2004. p.290.

10. Hunt M. Real time PCR tutorial [citado em 2 out. 2011]. Disponível em: http://pathmicro.med.sc.edu/ pcr/realtime-home.htm.

11. Berg JM, Tymoczko JL, Stryer L. Bioquímica. Rio de Janeiro: Guanabara Koogan, 2008: pp271-273.

12. Wehkamp J, Chu H, Shen B, Feathers RW, Kays RJ, Lee SK, Bevins CL. Paneth cell antimicrobial peptides: topographical distribution and quantification in human gastrointestinal tissues. FEBS Lett. 2006;580:534450.

13. Saiki RK, Gelfand DH, Stoffel S, Scharf SJ, Higuchi R, Horn GT, et al. Primer-directed enzymatic amplification of DNA with a thermostable DNA polymerase. Science. 1988;239:491-7.

Artigo recebido em: 30/11/10

Artigo aceito em: 20/01/11 